\title{
In utero undernutrition impairs rat beta-cell development
}

\author{
A . G arofano, P. C zernichow, B . B réant \\ INSERM U 457, Hôpital Robert Debré, Paris, France
}

Summary The role of nutrition on the development of the endocrine pancreas was studied in a rat model obtained by maternal food restriction. A $50 \%$ food restriction was applied to female rats from day 15 of pregnancy and resulted in intrauterine growth-retardation (IUGR) in the offspring. At day 1 postnatal, beta-cell mass was significantly decreased in IUGR pups as compared to controls $(0.70 \pm 0.06$ vs $1.07 \pm 0.06 \mathrm{mg}, p<0.0001)$, as well as insulin content. This change in beta-cell mass can be attributed to a reduced number of islets, since the density of insulinpositive aggregates in pancreatic sections of IUGR rats was $20 \%$ lower than in controls. Proliferative capacity of beta cells, as measured by 5-bromo-2-deoxyuridine (BrdU) labelling index, was not altered in growth-retarded animals. Body as well as pancreatic weight were fully recovered in IUGR pups after 21 days of normal feeding by control mothers. However, these animals retained a $25 \%$ decrease in insulin content, $40 \%$ decrease in beta-cell mass $(1.58 \pm 0.18$ vs $2.78 \pm 0.42 \mathrm{mg}, p<0.001)$ and a strong reduction in the density of insulin positive aggregates per $\mathrm{cm}^{2}$, as compared to controls, suggesting that the total islet number was likely to be reduced. Beta-cell proliferative capacity remained normal. In conclusion, in utero undernutrition in rats does not impede postnatal growth but durably impairs beta-cell development. Impairment of beta-cell differentiation might be suggested. [Diabetologia (1997) 40: 1231-1234]

Keywords Beta cell, proliferation, rat, nutrition, immunohistochemistry, morphometry.
Beside growth factors such as growth hormone, prolactin and insulin-like growth factor-I, glucose is known as an important stimulus for beta-cell growth in both fetal and adult life. In vitro studies have also shown that proliferation of fetal beta cells can be stimulated by amino acids [1]. Although scarce, in vivo studies suggest that in utero nutrition influences beta-cell development, leading to important postnatal changes in the metabolism. Experimental diabetes in pregnant rats can induce an increase or a reduction of fetal beta-cell mass in late fetuses, depending respectively on whether the diabetes in mothers is

Received: 20 May 1997 and in final revised form: 30 June 1997

Corresponding author: Dr. B. Bréant, INSERM U 457, Hôpital Robert Debré, 48 boulevard Sérurier, 75019 Paris, France A bbreviations: IUGR, Intrauterine growth retardation; BrdU, 5-bromo-2-deoxyuridine; PBS, phosphate buffered saline moderate [2] or severe [3]. In utero poor nutrition is also known to induce low birth weight [4]. Furthermore, maternal low-protein-isocaloric diet given throughout pregnancy alters both islet size and islet cell proliferative capacity in the neonates [5]. However, the impact of such undernutrition on the betacell itself is presently not known. In the young rat, protein-energy malnutrition after weaning dramatically impairs beta-cell mass that is not reversed following nutritional rehabilitation [6]. The purpose of the present work was to document the impact of malnutrition on the beta cells during some of their active phases of development. Given the crucial role of nutrients on beta cell growth and function, global food restriction of the mother was applied from day 15 of pregnancy and the status of beta cells in the severely growth retarded offspring was determined by quantitative morphometry on pancreatic sections. In order to gain more insight into the mechanisms underlying 
Table 1. Body weight, pancreas weight and comparative morphometric parameters of beta cells in control and intrauterine growth retarded (IUGR) animals at day 1 and 21

\begin{tabular}{|c|c|c|c|c|}
\hline \multirow[t]{2}{*}{ Group } & \multicolumn{2}{|l|}{ Day 1} & \multicolumn{2}{|l|}{ Day 21} \\
\hline & Control & IUGR & Control & IUGR \\
\hline Body weight (g) & $7.3 \pm 0.6$ & $6.0 \pm 0.3^{\mathrm{a}}$ & $54.1 \pm 3.6$ & $51.4 \pm 3.8$ \\
\hline Insulin ( $\mu \mathrm{g} /$ pancreas) & $8.5 \pm 1.2$ & $5.2 \pm 0.9^{\mathrm{a}}$ & $48.5 \pm 2.9$ & $38.5 \pm 4.5^{\mathrm{c}}$ \\
\hline Insulin ( $\mu \mathrm{g} / \mathrm{g}$ body weight $)$ & $1.21 \pm 0.17$ & $0.91 \pm 0.17^{\mathrm{c}}$ & $0.91 \pm 0.10$ & $0.75 \pm 0.09^{\mathrm{d}}$ \\
\hline Beta-cell density (\%) & $3.65 \pm 0.35$ & $2.74 \pm 0.19^{\mathrm{b}}$ & $1.21 \pm 0.14$ & $0.76 \pm 0.10^{\mathrm{b}}$ \\
\hline Beta-cell mass (mg) & $1.07 \pm 0.06$ & $0.70 \pm 0.06^{\mathrm{a}}$ & $2.78 \pm 0.42$ & $1.58 \pm 0.18^{\mathrm{b}}$ \\
\hline Beta-cell labelling index (\%) & $3.02 \pm 0.10$ & $2.99 \pm 0.31$ & $1.22 \pm 0.18$ & $1.03 \pm 0.15$ \\
\hline Beta-cells per islet section & $30.7 \pm 2.0$ & $32.6 \pm 2.5$ & $34.6 \pm 8.9$ & $35.7 \pm 2.9$ \\
\hline Insulin positive cell aggregates $/ \mathrm{cm}^{2}$ & $1142 \pm 113$ & $918 \pm 104^{c}$ & $358 \pm 53$ & $226 \pm 35^{b}$ \\
\hline
\end{tabular}

For body weight and pancreas weight values are mean \pm SD of 14 different animals. Insulin content was measured in whole pancreases of 7 animals per group. Values for individual betacell area represent mean \pm SD of 100 cells chosen on various sections in each group. All other values are mean \pm SD of 5 dif-

a possible impairment of beta-cell development, the proliferative capacity of the beta cell and the density of insulin-positive aggregates, reflecting the islet number, were determined.

\section{Animals and methods}

Three-month-old pregnant Wistar rats (Janvier, Le Genêt-St. Isle, France), were caged individually with free access to tap water. All animals were fed a standard laboratory rat chow (UAR, Villemoisson-sur-Orge, France). Control females were fed ad libitum whereas those intended for the malnutrition study were food-restricted to $50 \%$ of daily control intake (determined in a pilot study) and were given $12 \mathrm{~g}$ per day, from day 15 of pregnancy until delivery. At parturition, pups with severe intra-uterine growth retardation (IUGR) were selected before suckling (body weight $\leq$ control weight -2 SD) and represented approximately $40 \%$ of the population born from the food-restricted dams. Both control and IUGR pups (8 per litter) were nursed by control mothers; males and females were mixed. Pups were killed by decapitation; basal insulinaemia and glycaemia were not different from control values at days 1 and 21 (not shown). These studies were approved by the French Animal Ethics Committee.

One hour before killing, the animals received i.p injection of 5-bromo-2-deoxyuridine (BrdU, $50 \mathrm{mg} / \mathrm{kg}$ body weight) [7]. The whole pancreas was fixed in $4 \%$ paraformaldehyde-phosphate buffered saline (PBS), successively immersed in $15 \%$ (overnight) and $30 \%(2 \mathrm{~h})$ sucrose-PBS solutions, frozen and kept at $-20^{\circ} \mathrm{C}$. Each pancreas was subsequently sectioned ( $6 \mu \mathrm{m}$ thick) throughout its length and 5-7 sections taken at regular intervals were analysed per pancreas. Sections were treated with $4 \mathrm{~N} \mathrm{HCl}\left(10 \mathrm{~min}, 37^{\circ} \mathrm{C}\right)$ and simultaneously incubated with guinea pig anti-insulin (Dako, Trappes, France) and monoclonal mouse anti-BrdU (Sigma, La Verpillière, France) antibodies. Insulin-positive cells were stained with nitroblue tetrazolium after incubation with an alcaline phosphatase anti-rabbit antibody (Promega, Lyon, France). Proliferating cells were detected using the avidin-biotin-peroxidase complex (Amersham, Les Ulis, France) with diaminobenzidine ferent animals in each group. Beta cells per islet section represent the mean number of insulin-positive cells per sectioned aggregate (islet).

${ }^{\mathrm{a}} \mathrm{p} \leq 0.0001,{ }^{\mathrm{b}} \mathrm{p} \leq 0.001,{ }^{\mathrm{c}} \mathrm{p} \leq 0.01,{ }^{\mathrm{d}} \mathrm{p}<0.05$, compared to controls

as chromogen. BrdU labelling index estimated in acinar cells was similar in control and IUGR sections (control: $10.8 \pm 1.3$, vs IUGR: $10.5 \pm 2.1 \%$ at day 1 , and control: $3.7 \pm 0.2$ vs IUGR: $3.8 \pm 0.8 \%$ at day 21$)$, thereby excluding an uptake bias of the compound. Computer assisted measurements were done with a Leica DMRB microscope equipped with a colour video camera connected to a Quantimet $500 \mathrm{MC}$ computer (screen magnification $\times 24$ ). The area of insulin-positive cells was measured on the entire section (final magnification $\times 120$ ). The area of the pancreatic tissue was similarly measured by phase contrast. Beta-cell density was calculated in each section as the ratio of insulin-positive area to the total area of the section. Absolute beta-cell mass was calculated as the product of mean beta-cell density by pancreatic weight. Individual betacell size was manually measured (final magnification $\times 960$ ) after light counterstaining. From these measurements, total betacell number in the section was deduced. Beta-cell labelling index was determined (final magnification $\times 480$ ) as the percentage of insulin-positive cells which were also positive for BrdU on the entire section. Aggregates composed of more than three immunoreactive insulin cells (diameter $>25 \mu \mathrm{m}$ ) were counted on each section, yielding the density expressed as number of aggregates per $\mathrm{cm}^{2}$. Pancreatic insulin was measured by RIA using monoiodinated porcine insulin as tracer (Sorin Biomedica, Saluggia, Italy), guinea pig anti-insulin antibody (provided by C. Van Schravendijk, Brussels, Belgium) and purified rat insulin as standard (Novo Nordisk, Boulogne, France), after acid-ethanol extraction.

Statistical analysis. All values, expressed as mean $\pm \mathrm{SD}$, were statistically analysed by unpaired Student's t-test.

\section{Results and discussion}

Maternal food restriction from day 15 of gestation did not affect length of gestation, litter size or mortality rate, but significantly decreased birth weight (16\%) in the offspring from restricted dams. The mean birth weight (day 0) for these newborns was $5.50 \pm 0.38$ vs $6.25 \pm 0.51 \mathrm{~g}$ for controls $(p<0.001)$. The impact of 


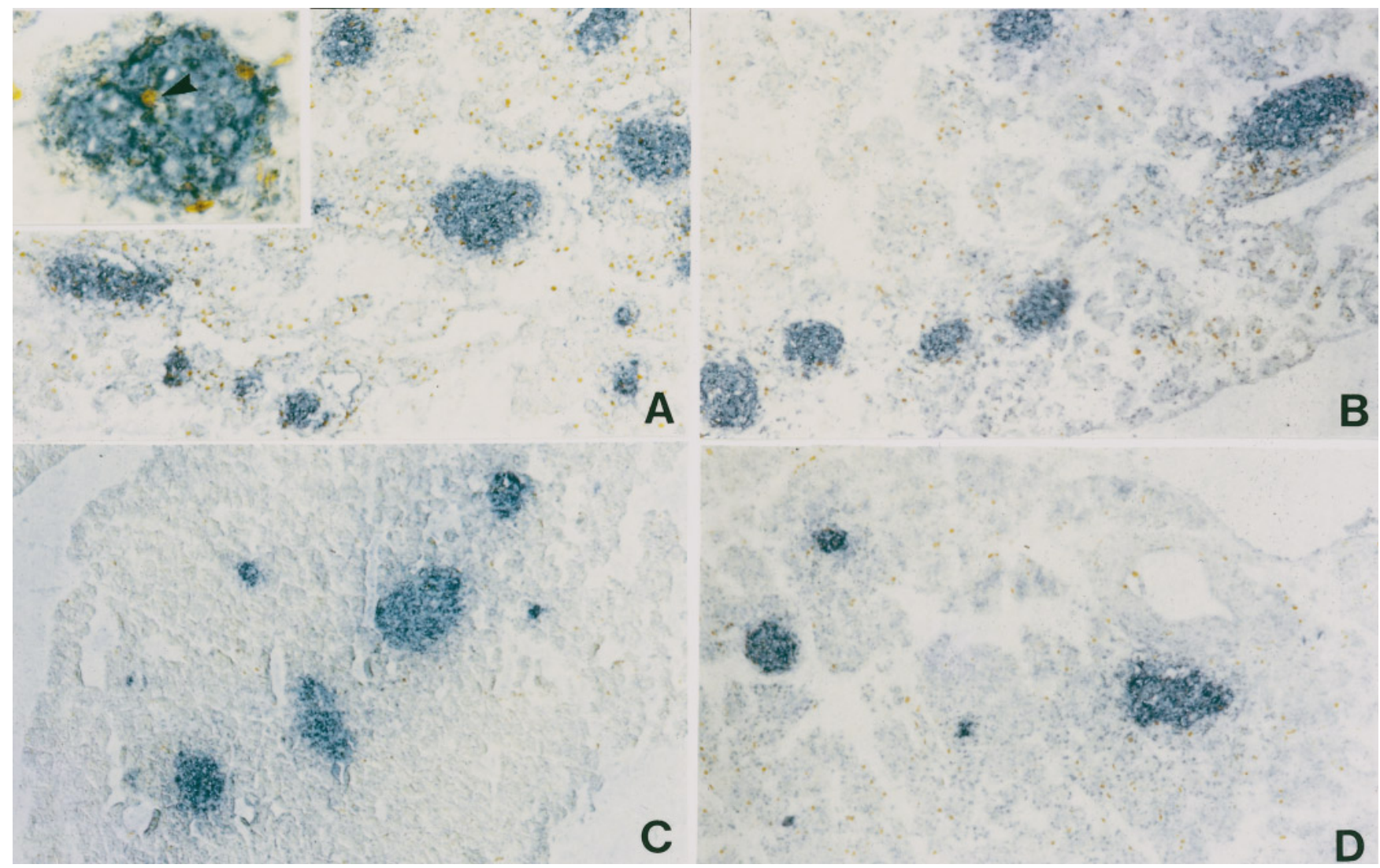

Fig. 1A - D. Immunohistochemical double staining for BrdU (brown nuclei) and insulin (blue) in rat pancreata from control $(\mathbf{A}, \mathbf{C})$ and IUGR (B, D ) animals at day $1(\mathbf{A}, \mathbf{B})$ and $21(\mathbf{C}, \mathbf{D})$ postnatal. Note the difference in the density of insulin-positive cell aggregates. Original magnification, $\times 100$. Inset: arrowhead indicates double positive cell, original magnification $\times 400$

malnutrition on pancreatic development was studied in the newborns with severe intra-uterine growth retardation (IUGR), which, as previously defined, concerned $40 \%$ of the undernourished animals. At $12 \mathrm{~h}$ of life (denoted day 1 ), IUGR pups showed $25 \%$ decrease in beta-cell density, $30 \%$ decrease in the absolute beta-cell mass and about $40 \%$ decrease in total insulin content as compared to controls (Table 1). These alterations were somewhat more pronounced than those observed in the endocrine pancreas after uterine artery ligation [8] or protein restriction [5]. Such differences may be linked to the degree of in utero undernutrition induced by these different methods. Alternatively, quantitative results may vary with the staining techniques used to reveal beta cells, histological staining or immunoreactivity for insulin. This seems unlikely since values of beta-cell density and mass for control animals on days 1 and 21 were comparable with those previously reported [7, 9]. The reduction of beta-cell mass observed in IUGR pups cannot solely be explained by the slight reduction in beta-cell size (Table 1), implying therefore a decrease in the total number of beta cells.

Two processes are generally admitted to account for the formation of new beta cells: differentiation, i.e. neoformation of beta cells from precursor cells, and proliferation of pre-existing beta cells $[1,7,9]$. In order to gain more insight into the mechanism underlying the impairment of beta-cell development, proliferative capacity of the beta cells was investigated. BrdU labelling index measured in insulin-positive cells was comparable between control and IUGR rats (Table 1). In line with this result, similar mean betacell numbers were found per sectioned insulin-positive aggregate in control and IUGR animals (Table 1). These results indicate that the decrease in beta-cell mass does not result from a decreased betacell proliferation, and raises the idea of an impairment in the differentiation process. The latter is supported by the significant decrease $(20 \%)$ in the density of insulin-positive cell aggregates, thereby suggesting a decrease in the total number of islets.

Similar analyses were performed at day 21 postnatal in IUGR rats nursed by control mothers. Although these animals recovered their normal body and pancreatic weights, they still displayed $25 \%$ reduction in total insulin content, $40 \%$ reduction in beta-cell mass and $30 \%$ reduction in the number of insulin-positive cell aggregates per $\mathrm{cm}^{2}$, likely to reflect the islet density (Table 1, Fig. 1). Beta-cell proliferative capacity remained normal in IUGR rats as 
compared to controls (Table 1 ). The results obtained at 21 days postnatal suggest that in utero malnutrition leads to irreversible alterations in beta-cell development which are not compensated for by an increase in beta-cell proliferation, suggesting that they may originate from abnormal differentiation. The extent of the alteration of beta-cell mass is in line with the stunting of beta-cell growth previously described in young rats fed a low-protein diet at weaning [6]. However, the normal beta-cell proliferation found in the present study is in contrast with the altered proliferative capacity suggested in the same study [6]. This discrepancy supports the idea that the mechanisms by which malnutrition affects beta-cell development may vary with the period during which it takes place. Differentiation may be altered at fetal stages while proliferation may be affected after weaning. Taken together, these results suggest that in utero malnutrition impairs neogenetic capacity of the fetus, leading to irreversible alterations in beta-cell development that cannot be compensated for by normal postnatal feeding.

A cknowledgements. The authors thank B. Blondeau for adapting the imaging software. This work was funded by INSERM and Fondation pour la Recherche Médicale. We also thank Novo Laboratories for financial support to A. G.

\section{References}

1. Hellerström C, Swenne I (1985) Growth pattern of pancreatic islets in animals. In: Wolk BW, Arquilla ER(eds) The diabetic pancreas. Plenum Press, New York pp 53-79

2. Aerts L, Van Assche FA (1977) Rat fetal endocrine pancreas in experimental diabetes. J Endocrinol 73: 339-346

3. Eriksson U, Swenne I (1982) Diabetes in pregnancy: growth of the fetal pancreatic B cells in the rat. Biol Neonate 42: 239-248

4. Gluckman P, Harding J (1992) The regulation of fetal growth. In: Hernandez M, Argente J (eds) Human growth, basic and clinical aspects. Elsevier, Amsterdam, pp 253-286

5. Snoeck A, Remacle C, Reusens B, Hoet J (1990) Effect of a low protein diet during pregnancy on the fetal rat endocrine pancreas. Biol Neonate 57: 107-118

6. Swenne I, Borg L, Crace C, Landström AS (1992) Persistent reduction of pancreatic beta-cell mass after a limited period of protein-energy malnutrition in the young rat. Diabetologia 35: 939-945

7. Wang R, Bouwens L, Klöppel G (1994) Beta-cell proliferation in normal and streptozotocin-treated newborn rats: site, dynamics and capacity. Diabetologia 37: 1088-1096

8. De Prins FD, Van Assche FA (1982) Intra-uterine growth retardation and development of endocrine pancreas in the experimental rat. Biol Neonate 41: 16-21

9. Scaglia L, Cahill CJ, Finegood DT, Bonner-Weir S (1997) Apoptosis participates in the remodeling of the endocrine pancreas in the neonatal rat. Endocrinology 138: 1736-1741 